\title{
KORELASI KADAR LAJU ENDAP DARAH DENGAN NILAI ASPECTS PADA PASIEN STROKE ISKEMIK
}

\author{
Ratih Ismiranti Murni', Dwi Pudjonarko², Bambang Satoto', Sukma Imawati ${ }^{1}$
}

\begin{abstract}
Abstrak
Stroke adalah penyebab utama ke-3 kematian di Amerika Serikat. Stroke iskemik adalah kondisi kompleks dengan etiologi dan manifestasi klinis bervariasi. CT Scan kepala adalah pencitraan darurat stroke membedakan dengan perdarahan intrakranial. Beberapa peneliti mengemukakan adanya korelasi independent dan hubungan pemeriksaan rutin biomarkers pada pasien stroke iskemik akut termasuk di dalamnya parameter inflamasi yang berperan pada patofisiologi iskemia otak. Tujuan penelitian ini mengetahui korelasi kadar LED dengan penilaian ASPECTS pada pasien stroke iskemik. Penelitian ini merupakan penelitian observasional analitik belah lintang dari catatan rekam medik. Selama periode Desember 2012 - Oktober 2014. Didapatkan 16 sampel yang memenuhi kriteria inklusi dan ekslusi. Dengan beberapa karakteristik subyek penelitian meliputi usia, jenis kelamin, hipertensi, diabetes mellitus, dislipidemia, kadar LED 1 dan 2, awitan stroke iskemik akut. Uji statistik Rank Spearman's,dan uji bivariat maupun multivariat. Didapatkan hasil tidak ada korelasi antara nilai ASPECTS dengan kadar LED dan faktor yang mempengaruhi nilai ASPECTS.
\end{abstract}

Kata kunci: Stroke iskemik, biomarker, LED, ASPECTS

\begin{abstract}
Stroke is the third major cause of death in United States. Ischemic stroke results from complex conditions with various etiologies and clinical manifestations. Brain CT Scan is a stroke emergency imaging to differentiate intracranial hemorrhage. Several studies claimed there were independent correlation and relationship of biomarker in routine examination of acute ischemic stroke patients including inflammation parameters that contribute to the pathophysiology of brain ischemic. The purpose in this study was to identify correlation between ESR level and ASPECTS in ischemic stroke patients. The method of study was analytical observational cross sectional taken from medical record. It was performed in 16 patients that fulfill the inclusion and exclusion criteria during December 2012- October 2014. Several characteristics of subject that affecting ASPECTS included age, gender, hypertention, diabetes mellitus, dyslipidemia, ESR level 1 and 2 , and onset of acute ischemic stroke were assessed. Analytical test was performed by Rank spearman's test and multivariate test. There was no correlation between ASPECTS with ESR level and factors that affect ASPECTS.
\end{abstract}

Keywords: ischemic stroke, biomarker, ESR, ASPECTS

Afiliasi Penulis: 1. Bagian Radiologi, Fakultas Kedokteran Universitas Diponegoro / RS dr. Kariadi Semarang, 2. Bagian Neurologi, Fakultas Kedokteran Universitas Diponegoro / RS dr. Kariadi Semarang. Korespondensi : Ratih Ismiranti Murni, Bagian Radiologi, Fakultas Kedokteran Universitas Diponegoro / RS dr. Kariadi Semarang, JI.Dr.Sutomo No.16 Semarang, Email: ratihismiranti@yahoo.com, Telp \HP: +6285722182823 


\section{PENDAHULUAN}

Stroke adalah penyebab utama ketiga kematian di Amerika Serikat. Dari sekitar 700.000 terjadi stroke setiap tahun, sekitar 550.000 adalah stroke pertama. Sekitar 400.000 adalah stroke iskemik.(1) Stroke iskemik adalah kondisi yang kompleks dengan beberapa etiologi dan manifestasi klinis bervariasi.2,3 Early ischaemic changes (EIC) pada NCCT akan ditemukan gambaran hiperdensitas arteri yang sering terjadi pada proksimal Middle cerebral Artery ( MCA), hipodensitas pada nukleus lentiformis, hilangnya insular ribbon (batas grey dan white matter), hilangnya diferensiasi antara grey matter dan white matter, menghilangnya sulkus pada hemispere dan kompresi lokal pada ventrikel lateral. Sejumlah perubahan penting akibat proses iskemik akut bervariasi. Sebelumnya radilogist beranggapan bahwa pemeriksaan CT Scan beberapa jam dari onset stroke memiliki sensitivitas rendah, ${ }^{(4)}$ sehingga radiologist bersepakat untuk meningkatkan sensitivitasnya dalam evaluasi stroke iskemik akut melalui pemeriksaan CT Scan secara sistematis menggunakan sistem The Alberta stroke program early CT score (ASPECTS).

ASPECTS adalah sistem skoring yang dilakukan dengan pemeriksaan pencitraan computed tomografi non Contrast (NCCT), untuk menilai perubahan teritori MCA pada stroke fase awal. Area teritori arteri serebri media (MCA) terbagi atas 10 regio pada skoring menggunakan ASPECT. ${ }^{3}$

ASPECTS penting untuk memutuskan terapi trombolisis yang berguna pada pasien dengan luas iskemik kurang dari $1 / 3$ teritorial dari MCA, dimana skor ASPECT 7 atau kurang menunjukkan lesi iskemik lebih dari $1 / 3$ teritorial MCA. Hal ini berhubungan dengan peningkatan risiko terjadi perdarahan pada terapi trombolisis. ${ }^{3,5}$

Beberapa penelitian menunjukan adanya korelasi independent dan hubungan pemeriksaan rutin biomarkers pada pasien stroke iskemik akut termasuk di dalamnya parameter inflamasi, dan ukuran serta letak lesi iskemik di otak $\cdot 6,7$ Kegunaan biomarker memberikan pengaruh kuat untuk memahami patofisiologi dan pendekatan dalam pengobatan stroke. ${ }^{6,7}$ Biomarker yang akan kami periksa yaitu LED atau laju endap darah berhubungan dengan ASPECTS score pada pasien stroke iskemik. Laju endap darah juga didefinisikan sebagai kecepatan pengendapan sel-sel eritrosit dalam plasma. ${ }^{8}$

Hasil pemeriksaan LED digunakan sebagai penanda non spesifik perjalanan penyakit, khususnya memantau proses inflamasi dan aktivitas penyakit akut. $^{9}$ Nilai LED yang di observasi segera setelah acute Ischaemic Stroke (AIS) memberikan refleksi derajat respon pada fase awal AIS dan perluasan dari kerusakan otak lokal. ${ }^{10,11}$

Penelitian ini bertujuan untuk mendeskripsikan nilai ASPECTS pada pasien dengan stroke iskemik, menilai kadar LED pada pasien stroke iskemik, dan menganalisis korelasi antara kadar LED dengan nilai ASPECTS pada pasien stroke iskemik.

\section{METODE}

Penelitian ini merupakan penelitian observasional analitik dengan rancangan belah lintang dari catatan rekam medik. Ruang lingkup penelitian adalah 
Radiologi, Rekam Medik dan Patologi Klinik RS.KARIADI Semarang pada rentang waktu Desember 2012 sampai Oktober 2014. Sampel penelitian adalah pasien stroke iskemik fase akut yang berobat dan di rawat di RSU Kariadi dari data rekam medik yang memenuhi kriteria inklusi dan ekslusi.

Dengan metoda consecutive sampling. Besar sampel di hitung berdasarkan rumus perhitungan data nu-merik sebayak 16 sampel. Penelusuran dari data rekam medik pasien kemudian subyek yang memenuhi kriteria inklusi dilakukan penilaian ASPECTS oleh dua radiolog. ASPECTS dinilai dengan menggunakan CT scan kepala topografik kepala non kontras dengan 64-MDCT scanner somatom sensation, Siemen dengan window width (W) $100 \mathrm{HU}$ dan centre length (C) $45 \mathrm{HU}$, setinggi ganglia basalis dan korona radiata. Kemudian subyek diperiksa kadar LED I dan II ( S dari 7 hari setelah onset ).

\section{HASIL DAN PEMBAHASAN}

Karakteristik subyek penelitian meliputi variabel faktor demografis dan faktor risiko vaskuler. Faktor demografis terdiri dari usia dan jenis kelamin. Karakteristik risiko vaskuler yang dianalisa pada penelitian ini adalah hipertensi, diabetes mellitus, dislipidemia, kadar laju endap darah 1 dan 2. Karakteristik infark iskemik akut yang dinilai adalah pada area teritori arteri serebri media berdasarkan ASPECTS (Alberta Stroke Program for Early CT Score ).

Perbandingan jenis kelamin pada sampel penelitian adalah $8(50 \%)$ pada laki-laki dan 8 (50\%) pada perempuan dengan nilai median umur dari sampel penelitian kami yang berjumlah 16 orang adalah 62,00 (SD $\pm 8,809)$ tahun. Umur termuda 47 tahun dan umur tertua 78 tahun. Berdasarkan nilai ASPECTS yang memenuhi kriteria inklusi dengan nilai ASPECTS $\leq 7$ ( $>1 / 3$ dari teritorial MCA ) sebanyak 7 subyek (43,8 \%) dan yang mempunyai nilai ASPECTS $>7(<1 / 3$ dari teritorial MCA ) sebanyak 9 subyek ( $56,3 \%$. Pada penelitian ini didapatkan kadar LED 1 tinggi (>0-2 mm/jam) pada 16 subyek dengan stroke iskemik akut adalah 52,06 mm/jam dan kadar LED 2 tinggi ( $>6-20 \mathrm{~mm} / \mathrm{jam}$ ) pada 16 subyek dengan stroke iskemik adalah 103,69 $\mathrm{mm} / \mathrm{jam}$. Faktor risiko vaskuler hipertensi 12 subyek (75\%), kolesterol tinggi 12 subyek (75\%), LDL tinggi 11 subyek $(68,75 \%)$.

Jumlah subyek nilai ASPECTS $\leq$ 7 terbanyak pada usia 60 tahun, nilai ASPECTS $>7$ terbanyak pada usia $>60$ tahun. Jumlah subyek dengan nilai ASPECTS $\leq 7$ terbanyak terdapat pada perempuan, nilai ASPECTS $>7$ terbanyak pada laki-laki. Untuk kadar LED I dan II dengan nilai ASPECTS $\leq 7$ dan nilai ASPECTS $>7$ didapatkan hasil kadar LED tinggi. Pada nilai ASPECTS $\leq$ 7 dan nilai ASPECTS $>7$ terbanyak pada subyek yang mengalami hipertensi. Nilai ASPECTS $\leq 7$ dan ASPECTS $>7$ dari penelitian di dapatkan pada subyek yang tidak mempunyai riwayat diabetes mellitus. Sedangkan untuk hiperkolesterolemia di dapatkan pada subyek dengan nilai ASPECTS $\leq 7$ dan nilai ASPECTS $>7$. Untuk kadar LDL tinggi di dapatkan pada subyek dengan nilai ASPECTS $\leq 7$ dan nilai ASPECTS $>7$ (tabel 1).

Hasil uji korelasi Rank Spearman's tersebut tidak menunjukkan 
adanya korelasi atau hubungan bermakna antara nilai ASPECTS dengan kadar laju endap darah dan yang mempengaruhi nilai ASPECTS seperti umur, kolesterol, kadar LDL, hipertensi, diabetes mellitus dan jenis kelamin yang dilakukan dengan uji Chi-square dan di dapatkan nilai $p>0,05$, menunjukan tidak adanya hubungan yang bermakna antara nilai ASPECTS dengan kolesterol, kadar LDL, hipertensi, diabetes mellitus dan jenis kelamin (Tabel 2 dan 3 ).

Tabel 1. Karakteristik faktor-faktor yang mempengaruhi nilai ASPECTS

\begin{tabular}{|c|c|c|c|}
\hline \multirow{2}{*}{\multicolumn{2}{|c|}{ VARIABEL }} & \multicolumn{2}{|c|}{ NILAI ASPECTS } \\
\hline & & $\begin{array}{l}\leq 7 \\
N=7 \\
N(\%)\end{array}$ & $\begin{array}{l}>7 \\
\mathrm{~N}=9 \\
\mathrm{~N}(\%)\end{array}$ \\
\hline 1 & $\begin{array}{l}\text { Usia } \\
->60 \text { tahun } \\
-\leq 60 \text { tahun }\end{array}$ & $\begin{array}{l}4(44,4 \%) \\
3(42,9 \%)\end{array}$ & $\begin{array}{l}5(55,6 \%) \\
4(57,1 \%)\end{array}$ \\
\hline 2 & $\begin{array}{l}\text { Jenis Kelamin } \\
\text { - Laki-laki } \\
\text { - Perempuan }\end{array}$ & $\begin{array}{l}3(42,9 \%) \\
4(44,4 \%)\end{array}$ & $\begin{array}{l}5(55,6 \%) \\
4(57,1 \%)\end{array}$ \\
\hline 3 & $\begin{array}{l}\text { Hipertensi } \\
\text { (retinopati) } \\
\text { - Ya } \\
\text { - Tidak }\end{array}$ & $\begin{array}{l}6(50,0 \%) \\
1(25,0 \%)\end{array}$ & $\begin{array}{l}9(56,3 \%) \\
3(75,0 \%)\end{array}$ \\
\hline 4 & $\begin{array}{l}\text { DM (retinopati) } \\
\text { - Ya } \\
\text { - Tidak }\end{array}$ & $\begin{array}{l}0(0 \%) \\
7(52,1 \%)\end{array}$ & $\begin{array}{l}0(\%) \\
9(56,3 \%)\end{array}$ \\
\hline 5 & $\begin{array}{l}\text { Hiperkolesterolemia } \\
\text { - normal } \\
\text { - tidak normal }\end{array}$ & $\begin{array}{l}1(25,0 \%) \\
6(50,0 \%)\end{array}$ & $\begin{array}{l}3(75,0 \%) \\
6(50,0 \%)\end{array}$ \\
\hline 6 & $\begin{array}{l}\text { Kadar LDL tinggi } \\
\text { - normal } \\
\text { - tidak normal }\end{array}$ & $\begin{array}{l}1(20,0 \%) \\
6(54,5 \%)\end{array}$ & $\begin{array}{l}4(80,0 \%) \\
5(45,5 \%)\end{array}$ \\
\hline 7 & $\begin{array}{l}\text { Kadar LED(1dan II) } \\
\text { - Tinggi } \\
\text { - Normal }\end{array}$ & $\begin{array}{l}7(52,1 \%) \\
0(0 \%)\end{array}$ & $\begin{array}{l}9(56,3 \%) \\
0(0 \%)\end{array}$ \\
\hline
\end{tabular}

Tabel 2. Korelasi kadar laju endap darah dengan nilai ASPECTS

$\begin{array}{lll} & \begin{array}{l}\text { Nilai ASPECTS } \\ \text { rho/correlation } \\ \text { cooficient }\end{array} & p \text {-value } \\ & 0,333 & 0,208 \\ \begin{array}{l}\text { ASPECTS-LED } \\ (1)\end{array} & 0,124 & 0,648 \\ \begin{array}{l}\text { ASPECTS-LED } \\ (2)\end{array} & & \\ & & \end{array}$

Tabel 3. Hubungan nilai ASPECTS dengan faktor-faktor yang mempengaruhi ASPECTS

\begin{tabular}{|c|c|c|}
\hline & Nilai & ASPECTS \\
\hline & Correlation & $p$-value \\
\hline & \multicolumn{2}{|l|}{ Coefficien/rho } \\
\hline Kadar LED I & .374 & .154 \\
\hline Kadar LED II & .165 & .542 \\
\hline Umur & $-.0,62$ & .820 \\
\hline Kolesterol & -.479 & $.0,61$ \\
\hline LDL & $-0,316$ & .234 \\
\hline
\end{tabular}

Pada penelitian ini menggunakan analisis uji koofisien regresi $p>0,05$, yang berarti tidak ada variabel yang berpengaruh terhadap nilai ASPECTS pada pasien dengan stroke iskemik (tabel 4).

The Alberta stroke program early CT score (ASPECTS) merupakan metode yang sistematis dan praktis yang dapat dijadikan standar untuk mendeteksi dan melaporkan tingkat perluasan dari stroke iskemik akut ${ }^{7}$ dan merupakan sistem skoring yang dilakukan dengan pemeriksaan imaging computed tomografi (CT) kepala non kontras yang digunakan untuk menilai perubahan pada fase iskemik awal (early ischaemic change/EIC) yang mengenai teritori arteri serebri media (MCA) pada stroke iskemik. Pada area teritori arteri serebri media (MCA) terbagi atas 10 regio pada skoring menggunakan ASPECTS. ${ }^{5}$

Karakteristik usia penderita stroke iskemik pada penelitian ini umur subjek dimulai 45 tahun keatas oleh karena stroke merupakan penyebab kematian paling tinggi yang mencapai $15,9 \%$ yang dimulai pada umur 45 tahun. ${ }^{(17)}$ 


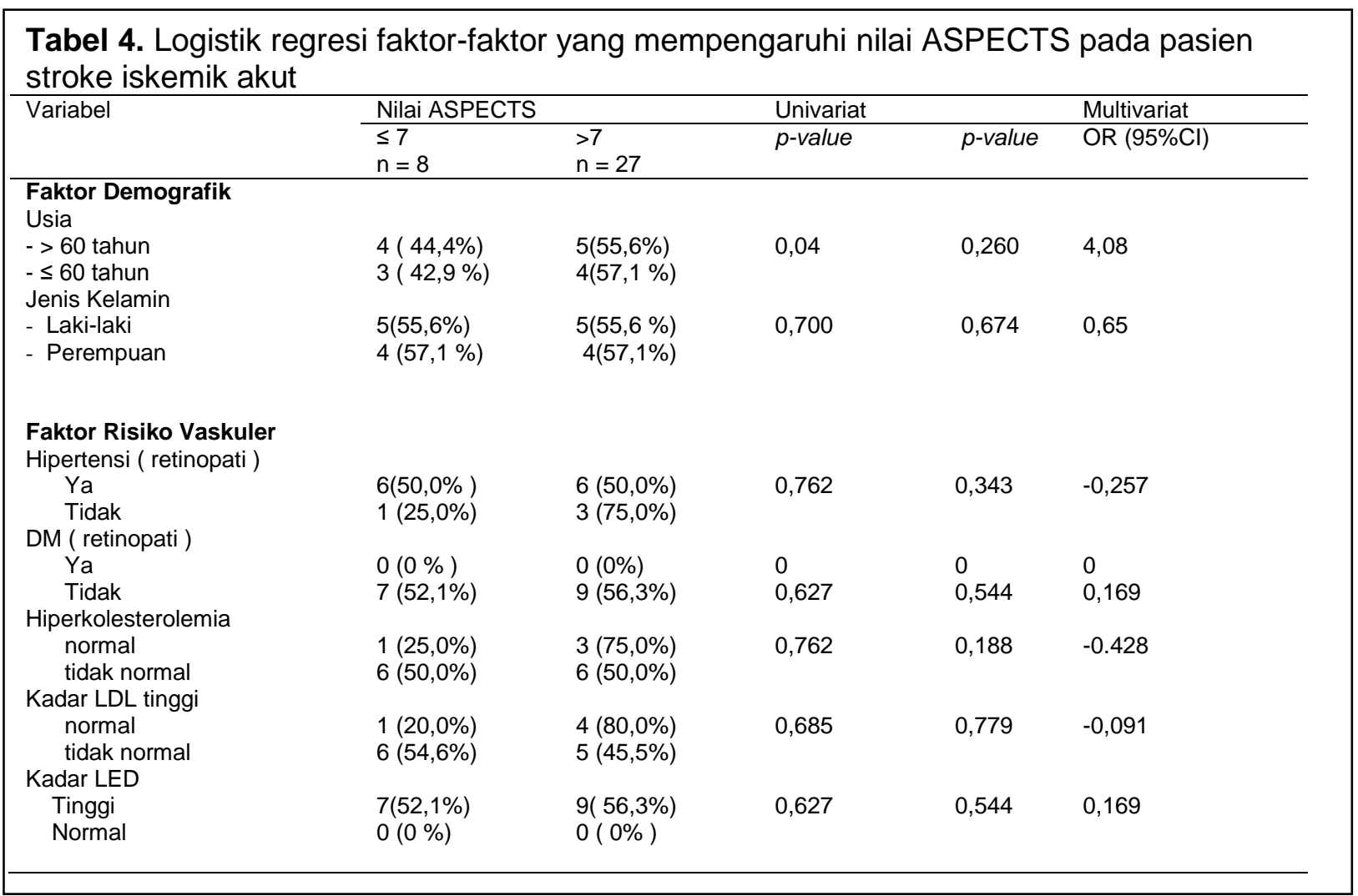

Pada penelitian ini didapatkan umur rerata sebesar $62,00 \mathrm{SD} \pm 8,809$ tahun, data penelitian oleh Rambe dkk, Sridharan dkk, di India mendapatkan median umur penderita stroke adalah 67 tahun yang mirip dengan penelitian ini 61,50 tahun. Adanya perbedaan angka harapan hidup yang berbeda pada setiap negara, sebuah data menunjukkan bahwa angka harapan hidup secara umum di Indonesia sebesar 70,67 tahun. $12,13,14,15,16,17$

Kadar laju endap darah plasma merupakan biomarker yang merupakan variabel utama pada penelitian ini sebagai faktor risiko vaskuler. Menyebabkan efek langsung pada sistem vaskuler dan secara tidak langsung pada sistem metabolik dan hemodinamik yang akhirnya meningkatkan resiko penyakit vaskuler. Pada penelitian ini menggunakan letak iskemik berdasarkan regio MCA ( Middle Cerebri Artery) saja, dan luas iskemik serta jumlah lesi yang terkena berdasarkan nilai ASPECTS. Dimana di didapatkan nilai LED I dan LED II dengan pengujian statistik menggunakan uji Rank Spearmen tidak didapatkan korelasi yang bermakna antara kadar laju endap darah dengan nilai ASPECTS yaitu stroke iskemik berdasarkan regio MCA (Middle Cerebri Artery) saja dan luas iskemik dinilai berdasarkan jumlah nilai ASPECTS area yang terkena lesi iskemik.

Pada penelitian ini secara statistik tidak terdapat hubungan bermakna antara faktor resiko vaskuler hipertensi dengan besarnya nilai ASPECTS. Hal ini sesuai dengan penelitian yang dilakukan oleh Kisialiou A dkk, yang mengatakan bahwa hipertensi tidak signifikan terhadap dimensi ukuran lesi iskemik. ${ }^{6}$ LDL 
dan kolesterol total pada penelitian ini secara statistik tidak terdapat hubungan bermakna dengan besarnya nilai ASPECTS.

Keterbatasan waktu pada penelitian yang kami lakukan, jumlah sampel yang kurang banyak yang masuk dalam keriteria inklusi, dengan metoda penelitian yang berbeda yaitu observasional analitik dengan mengambil sample dari data rekam medik yang mungkin tidak dapat mengontrol variabel-variabel yang tidak terindentifikasi yang mempengaruhi nilai ASPECTS.

\section{SIMPULAN}

Berdasarkan nilai ASPECTS yang memenuhi kriteria inklusi dengan nilai ASPECTS $\leq 7$ (> 1/3 dari teritorial MCA) sebanyak 7 subyek $(43,8 \%)$ dan yang mempunyai nilai ASPECTS $>7(<1 / 3$ dari teritorial MCA ) sebanyak 9 subyek ( $56,3 \%$. Pada penelitian ini didapatkan kadar Laju endap darah 1 yang tinggi (>0-2 mm/jam) pada 16 subyek dengan stroke iskemik akut adalah 52,06 $\mathrm{mm} / \mathrm{jam}$ dan kadar LED 2 yang tinggi (>6-20 mm/jam ) pada 16 subyek. Dan tidak di dapatkan korelasi atau hubungan yang bermakna antara kadar laju endap darah dengan nilai Alberta stroke program early ct score (ASPECTS) pada pasien stroke iskemik. Perlu penelitian lebih lanjut untuk melihat peran penanda inflamasi non spesifik lainnya seperti kadar leukosit, kadar CRP yang dihubungkan dengan nilai ASPECTS dengan menggunakan metoda penelitian secara observasional analitik prospektif.

\section{DAFTAR RUJUKAN}

1 Kral M, Herzig R, Sanak D, Skoloudik D, Vlachova I, Bartkova A, et al. Oral antiplatelet therapy in stroke prevention. Mini review. Biomed Pap Med Fac Univ Palacky. 2010; 154.

2 Moonis G, Pandey S, Dubey P. Acute Stroke Imaging : recent updates. Review article 2013 Apr $24:$ 1-6.

3 Myrtha R, Hanifah S. Gambaran CT Scan Non Kontras Pada Stroke Iskemik. CDK198/vol.39 no.10. 2012: 777-79.

4 Radhiana H, Syazarina S, Azura M, Hilwati $\mathrm{H}$, Sobri M. Non-contrast Computed Tomography in Acute Ischemic Stroke: a pictoral review. Continuing Medical Education. Med J Malaysia, 2013: 93-99.

5 Demchuk A, Hill MD, Barber PA, Silver B, Patel SC, Levine S. Importance of Early Ischemic Computed Tomography Changes Using ASPECTS in NINDS rtPA Stroke Study. A Guideline for Healthcare Professionals From the American Heart Association/American Stroke Association. Stroke. 2005: 1524-4628.

6 Kisialiou A, Pelone G, Carrizzo A, Grillea G, Trimarcos V, Marino M, et.al. Blood Biomarkers Role in Acute Ischemic Stroke Patients: Higher is Worse or Better? BioMed Central. 2012:1-10.

7 Zaremba J, Skrobański, P, Losy J. Acute Ischaemic Stroke Increases The Erythrocyte Sedimentation Rate, Which Correlates With Early Brain Damage. Folia Morphol. 2004: 373-376

8 Widodo D, Pohan T H. Manfaat klinik pemeriksaan laju endap darah. Bunga rampai : penyakit infeksi. Pusat Informasi dan Penerbitan Departemen IImu Penyakit Dalam Fakultas Kedokteran Universitas Indonesia.2004.

9 Heinrich P, Mattle, Michael, Brainin, Angel, Chamorro, Martin, Dichgans, et all. Early Prediction of Stroke Severity Role of the Erythrocyte Sedimentation Rate. Available from: http://stroke.ahajournals.org/search lauthor

10 Çomoğlu S.S, Çillier A.E, Güven H. Erythrocyte Sedımentation Rate: Can be $A$ Prognostic Marker In Acute Ischemi Stroke? Turkish Journal of Cerebrovascular Diseases 2013; 19 (1): 18-22

11 Idicula T.T, Brogger J, Naess $H$, Andreassen UW, dan Thomassen $\mathrm{L}$. Admission $C$ - reactive protein after acute ischemic stroke is associated with stroke severity and mortality: The 'Bergen stroke study'. BMC Neurology, 2008.9:18. 
12 Misbach, J, Ali, W.. Clinical Study. Stroke in Indonesia: A First Large Prospective Hospital-based Study of Acute Stroke in 28 Hospitals in Indonesia. Journal of Clinical Neuroscience, 8(3), 2000245-249.

13 Rambe, A.S, Fithrie, A, Nasution, I, Tonam. Profil pasien stroke pada 25 rumah sakit di Sumatera Utara 2012. Neurona, 2012. 30:63-68.

14 Sridharan, S.E, Unnikhrisnan, J.P, Sukumaran, S, Sylaja, P.N, Nayak, S.D, Sarma, P.S. Incidence, types, risk factor, and outcome of stroke in a developing country: the Trivandrum stroke registry. Stroke, 2009. 40:1212-1218.
15 Appelros, P, Stegmayr, B, Terent, A. Sex differences in stroke epidemiology: a systematic riview. Stroke, 2009.40:10821090.

16 Stroke Statistics [internet]. The Internet Stroke Center; (C) 1997-2013. [cited 2013 Dec 4]. Available from: http://www.strokecenter.org/patients/about-stroke/strokestatistics/

17 Merino J, Warach S. Imaging of acute stroke. Review. Nat. Rev. Neurol. 6, 560571 (2010). 